\title{
Collection devices influence the constituents of exhaled breath condensate
}

\section{To the Editors:}

The recent paper by Rosias et al. [1] reported that silicone and glass inner coatings were superior to the EcoScreen ${ }_{\circledR}$ system (Erich Jaeger $\mathrm{GmbH}$, Hochberg, Germany), aluminium, polypropylene and Teflon when measuring 8-isoprostane and albumin levels in exhaled breath condensate (EBC) [1-3]. This raises important issues in the ongoing debate about the optimal collection method for sampling airway biomarkers. We have complemented these important data by comparing the efficiency and reproducibility of EBC biomarkers collected by different devices in six healthy subjects.

Four collection systems were compared in a randomised order: glass, siliconised glass, EcoScreen $®$ and RTube ${ }^{\circledR}$ (Respiratory Research Inc., Charlottesville, VA, USA). Oxides of nitrogen $\left(\mathrm{NO}_{\mathrm{x}}\right)$, total protein, mucin and $\mathrm{pH}$ were measured and assessed for reproducibility over 3 days $[4,5]$.

The mean \pm SD EBC $\mathrm{NO}_{x}$ level after a 10-min collection period was significantly higher using the EcoScreen ${ }^{\circledR}(25.7 \pm 9.1 \mathrm{nmol})$ than either siliconised glass $(3.0 \pm 0.7 \mathrm{nmol})$ or RTube ${ }_{\circledR}$ $(3.7 \pm 0.7 \mathrm{nmol} ; \mathrm{p}<0.001$; fig. $1 \mathrm{a})$. Total protein per 10 -min collection was significantly higher using the EcoScreen $(18.6 \pm 7.3 \mu \mathrm{g})$ than either glass $(6.6 \pm 3.3 \mu \mathrm{g})$ or RTube ${ }^{k}$ $(7.0 \pm 2.9 \mu \mathrm{g} ; \mathrm{p}=0.017$; fig. 1b). Siliconised glass tubes showed a trend in their ability to collect more total protein in EBC compared with glass tubes; a larger sample size may have shown a significant difference $(n=107, \alpha=0.05,1-\beta=0.8)$. Mucin levels in EBC were not significantly different between the four devices $(p=0.52)$. No significant difference was found in $\mathrm{pH}$ in $\mathrm{EBC}$ between the four devices $(\mathrm{p}=0.34$, Friedman test). EBC collection was more efficient in the EcoScreen ${ }^{\circ}\left(21.8 \pm 2.4 \mu \mathrm{L} \cdot \mathrm{L}^{-1}\right.$ of breath) than the siliconised glass tubes $\left(12.8 \pm 1.9 \mu \mathrm{L} \cdot \mathrm{L}^{-1}\right.$ of breath; $\left.\mathrm{p}<0.05\right)$ or RTube ${ }_{\mathbb{R}}$ $\left(12.9 \pm 1.1 \mu \mathrm{L} \cdot \mathrm{L}^{-1}\right.$ of breath; $\mathrm{p}<0.05$; fig. $\left.1 \mathrm{c}\right)$.

$\mathrm{NO}_{x}$ levels were poorly reproducible and the median coefficient of variation for NOx concentrations was lowest in the EBC collected by the siliconised glass tube $(16.1 \%)$, although there was a large range $(0.0-67.4 \%)$. It has been demonstrated that $\mathrm{NO}_{\mathrm{x}}$ stability is associated with temperature, which may explain the relatively large coefficient of variation of $\mathrm{NO}_{x}$ using the RTube ${ }^{\circledR}$ [6], in which the temperature gradually increases from $-15^{\circ} \mathrm{C}$ to room or body temperature. The RTube ${ }_{\circledR}$ might be better used for monitoring markers not affected by collecting temperature. The EcoScreen ${ }$ seemed to have better reproducibility in terms of total protein levels in EBC, although there was no significant difference when compared with glass, siliconised glass or the $\mathrm{RTube}_{\mathbb{R}}$. $\mathrm{pH}$ was the most reproducible marker in all devices.
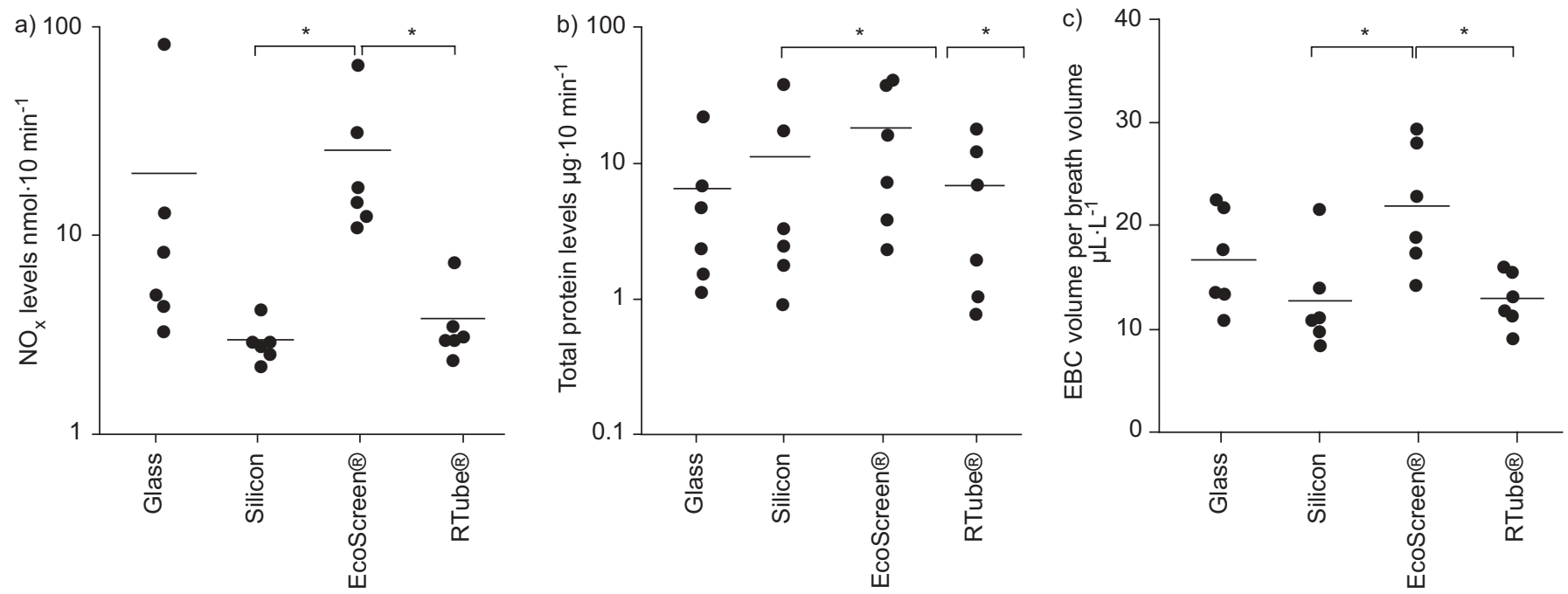

FIGURE 1. a) The total amount of oxides of nitrogen $\left(\mathrm{NO}_{x}\right)$ and b) the total protein levels in exhaled breath condensate (EBC) during a 10-min collection. c) The EBC volume per total breath volume. a) Total of $\mathrm{NO}_{x}$ was significantly higher in the samples collected using the EcoScreen® system (Erich Jaeger GmbH, Hochberg, Germany) when compared with either siliconised glass tubes or the RTube® (Respiratory Research Inc., Charlottesville, VA, USA) but did not differ significantly from the amounts collected by the glass tube apparatus. b) The total protein levels in EBC during 10-min EBC collection were significantly higher in the samples collected using EcoScreen when compared with either glass tubes or RTube ${ }_{\mathbb{B}}(p=0.017)$. c) The mean EBC volume per total breath volume collected using EcoScreen ${ }$ was significantly higher than those collected by either siliconised tube or RTubeß $(p=0.010)$. *: $p<0.05$. 
To determine whether the devices could contaminate samples with $\mathrm{NO}_{\mathrm{x}}$ or $\mathrm{H}^{+}$ions, distilled water, tap water and normal saline were incubated in each device. Baseline median (range) $\mathrm{NO}_{\mathrm{x}}$ levels were $1.2(1.0-2.2) \mu \mathrm{M}, 10.9(10.1-11.4) \mu \mathrm{M}$ and 1.2 $(0.5-1.7) \mu \mathrm{M}$ in distilled water, tap water and normal saline, respectively. $\mathrm{NO}_{x}$ levels were significantly increased in the EcoScreen ${ }^{\circledR}$ system (5.4 (2.2-7.3) $\mu \mathrm{M}$ in distilled water, 14.9 (14.3-19.8) $\mu \mathrm{M}$ in tap water and $4.4(2.4-5.9) \mu \mathrm{M}$ in normal saline $(\mathrm{p}=0.006))$ and in the $\mathrm{RTube}^{\circledR}(2.7(1.4-4.3) \mu \mathrm{M}$ in distilled water, $11.5(11.1-11.8) \mu \mathrm{M}$ in tap water and $2.6(1.2-$ 3.9) $\mu \mathrm{M}$ in normal saline $(\mathrm{p}=0.006))$ after a 10 -min incubation; there was no significant change in $\mathrm{NO}_{\mathrm{x}}$ levels in either glass tubes or siliconised glass tubes. No significant change was found in $\mathrm{pH}$ levels after $10 \mathrm{~min}$ of incubation in any device.

This study has confirmed that EBC collection devices influence the efficiency of collection but can also introduce errors in the measurement of markers. The EBC collected using the EcoScreen ${ }^{\circledR}$ system had the largest amount of $\mathrm{NO}_{\mathrm{x}}$ but also demonstrated poor inter-day and intra-day reproducibility. The higher efficiency of the EcoScreen ${ }_{\circledR}$ system in trapping the $\mathrm{NO}$ degradation product, $\mathrm{NO}_{\mathrm{x}}$, confirms our previous study [7], but is factitious and represents a contribution of $\mathrm{NO}_{x}$ from the device to aqueous media.

The EcoScreen ${ }^{\circledR}$ system had the highest amount of total protein levels in EBC compared with either the glass tube or the RTube and it also showed superior inter-day repeatability in total protein in this study. Higher protein levels in EBC collected by the most efficient device will aid identification quantification of EBC proteins, which may be near the lower limit of detection.

Mean total mucin levels in EBC were not significantly different between the four devices. In addition, glass and siliconised tubes had a trend to better reproducibility compared with the other two types of apparatus. An explanation may be that like other proteins, mucin is negatively charged and repulsed by glass, which also has a negative net charge [8].

In conclusion, collection devices significantly affect exhaled breath condensate biomarker levels and absolute values from different devices are not directly comparable. Siliconised glass showed the least variability in oxides of nitrogen levels, whilst the EcoScreen ${ }^{\circledR}$ was more consistent and efficient for protein collection, and also in terms of total exhaled breath condensate volume. This efficiency may in part be related to the lower temperature used in this device. We conclude that no single device is ideal for all applications. In future studies, each marker may need to be tested in a variety of devices to determine the optimal collection apparatus.

\section{J. Liu*,\#, D.H. Conrad", S. Chow", V.H. Tran ", D.H. Yates ${ }^{+}$ and P.S. Thomas, $*$,}

*Prince of Wales Clinical School, Faculty of Medicine, and 'School of Medical Sciences, Faculty of Medicine, University of New South Wales, Sydney, and "Dept of Respiratory Medicine, Prince of Wales Hospital, Randwick, and ${ }^{+}$Dept of Thoracic Medicine, St Vincent's Hospital, Darlinghurst, New South Wales, Australia.

\section{ACKNOWLEDGEMENTS}

We would like to thank Ratnawati (University of New South Wales, Sydney, New South Wales, Australia), A. Krishnan and G. Warwick (both St Vincent's Hospital, Darlinghurst, New South Wales, Australia) for their assistance in this study.

\section{STATEMENT OF INTEREST}

None declared.

\section{REFERENCES}

1 Rosias PP, Robroeks CM, Niemarkt HJ, et al. Breath condenser coatings affect measurement of biomarkers in exhaled breath condensate Eur Respir J 2006; 28: 1036-1041.

2 Rosias PPR, Vernooy JHJ, Dentener MA, et al. The inner coating of condenser systems influences the detection of human albumin in exhaled breath condensate Eur Respir J 2003; 22: Suppl. 45, 280s.

3 Rosias P, Robroeks C, Hendriks J, Dompeling E, Jobsis Q. Exhaled breath condensate: a space odessey, where no one has gone before Eur Respir J 2004; 24: 189-190.

4 Liu J, Thomas PS. Relationship between exhaled breath condensate volume and measurements of lung volumes Respiration 2007; 74: 142-145.

5 Jackson AS, Sandrini A, Campbell C, Chow S, Thomas PS, Yates DH. Comparison of biomarkers in exhaled breath condensate and broncho-alveolar lavage Am J Respir Crit Care Med 2007; 175: 222-227.

6 Yang F, Troncy E, Vinet B, Vinay P, Czaika G, Blaise G. Effects of reducing reagents and temperature on conversion of nitrite and nitrate to nitric oxide and detection of NO by chemiluminescence Clin Chem 1997; 43: 657-662.

7 Liu J, Chow S, Ratnawati, et al. Effect of collection materials upon markers of inflammation in exhaled breath condensate (abstract) Respirology 2006; 11: A31.

8 Van Klinken BJ, Dekker J, Buller HA, Einerhand AW. Mucin gene structure and expression: protection vs adhesion Am J Physiol 1995; 269: G613-G627.

DOI: $10.1183 / 09031936.00080207$ 